\title{
Liberal Transfusion versus Restrictive Transfusion and Outcomes in Critically III Adults: A Meta-Analysis
}

\author{
Wei Zhang ${ }^{a} \quad$ Yan Zheng $^{b} \quad K^{\prime}$ Yun Yu $^{\mathrm{a}} \quad$ Juan $\mathrm{Gu}^{\mathrm{c}}$ \\ ${ }^{a}$ Department of Critical Care Medicine, Affiliated Hospital of Zunyi Medical University, Zunyi, China; \\ ${ }^{b}$ Department of Ultrasound Medicine, Linyi City People's Hospital, Shandong, China; \\ 'Department of Clinical Pharmacy, Affiliated Hospital of Zunyi Medical University, Zunyi, China
}

Keywords

Anemia $\cdot$ Storage $\cdot$ Transfusion $\cdot$ Adverse effects $\cdot$ Blood transfusion

\section{Abstract}

Objective: We aimed to determine whether the restrictive red-cell transfusion strategy was superior to the liberal one in reducing all-cause mortality in critically ill adults. Methods: The MEDLINE, EMBASE, PubMed, Web of Science, and Cochrane Library Central Register of Controlled Trials databases were searched from inception to January 2019 to identify meta-analyses or systematic reviews and published randomized controlled trials which were restrictive versus liberal blood transfusion with mortality as the endpoint in critically ill adults. We used two search routes whereby one search was restricted to systematic reviews, reviews, or meta-analysis, and the other was not restricted. There were no date restrictions, but language was limited to English and the population was restricted to critically ill adults. The data of study methods, participant characteristics, and outcomes were extracted and analyzed independently by 2 reviewers. The main outcome was all-cause mortality. Results: Through screening the obtained records, we enrolled 7 randomized clinical trials that included information on restrictive versus
\end{abstract}

liberal red-cell transfusion and mortality of intensive care unit (ICU) patients. Involving a total of 7,363 ICU adult patients, ICU mortality (risk ratio [RR] 0.82, 95\% confidence interval [CI] 0.62, 1.08, $p=0.15$ ), 28/30-day mortality (RR 0.98, $95 \% \mathrm{Cl} 0.84,1.13, p=0.74), 60$-day mortality (RR $1.01,95 \% \mathrm{Cl}$ $0.87,1.16, p=0.91), 90$-day mortality (RR $1.02,95 \% \mathrm{Cl} 0.92$, $1.14, p=0.69), 120$-day mortality (RR $1.29,95 \% \mathrm{Cl} 0.67,2.47$, $p=0.44$ ), and 180-day mortality (RR $0.91,95 \% \mathrm{Cl} 0.75,1.12$, $p=0.38$ ) were not statistically significantly different when the restrictive transfusion strategy was compared with the liberal transfusion strategy. However, we surprisingly discovered that 112 out of 469 (24\%) patients who received a unit RBC transfusion when hemoglobin was less than $7 \mathrm{~g} / \mathrm{dL}$, and 142 out of 469 (30.3\%) who received a unit of RBC transfused with hemoglobin less than $9 \mathrm{~g} / \mathrm{dL}$, had died during hospitalization (RR $0.79,95 \% \mathrm{Cl} 0.64,0.97, p=0.03$ ). The results showed that the restrictive transfusion strategy could decrease in-hospital mortality compared with the liberal transfusion strategy. It was safe to utilize a restrictive transfusion threshold of less than $7 \mathrm{~g} / \mathrm{dL}$ in stable critically ill adults. Conclusions: In this study, we found that the restrictive redcell transfusion strategy potentially reduced in-hospital mortality in critically ill adults with anemia compared with the liberal strategy. 


\section{Introduction}

Red-cell transfusion plays an indispensable role in correcting anemia and blood loss in critically ill patients [1-3] However, as a life-saving therapy, a selection on the strategy of blood transfusion needs to be judiciously assessed in terms of trade-offs between benefits and risks. Evidence indicated transfusion was associated with adverse events and worse outcomes, including transfusion-related infection [4], acute lung injury [5], multiple organ failure [6], and risk of death [7]. Furthermore, multiple transfusions of red-cell units placed a heavy economic burden on patients [8]. Nevertheless, red-cell transfusion remains one of the most important treatments to save the lives of critically ill patients. For the above reasons, therefore, investigators are increasingly focusing on restrictive transfusion strategies. The strategy of restrictive red-cell transfusion could lessen the number of red-cell units and transfusion patients by reducing the threshold to $70 \mathrm{~g} / \mathrm{L}$ without an additional increase of morbidity and mortality in critically ill patients $[9,10]$. In the study of a model simulation of transfusion-related severe acute complications and costs, the results showed that the restrictive red-cell transfusion strategy was associated with the reduction of the quantity of red-cell transfusion and cost savings [11]. Current recommendations of advocating restrictive blood transfusion are primarily based on the Transfusion Requirements in Critical Care (TRICC) trial. In the TRICC trial, Hébert et al. [12] implied that the restrictive transfusion strategy (transfusion if the hemoglobin level is below $70 \mathrm{~g} / \mathrm{L}$ ) was as effective as and possibly better than the liberal transfusion strategy (transfusion if the hemoglobin level is below $90 \mathrm{~g} / \mathrm{L}$ ) in critically ill patients, and had a significantly lower 30-day mortality among those patients with an Acute Physiology and Chronic Health Evaluation II score $<20$ and age less than 55 years. The restrictive transfusion strategy was proven to be safe in the majority of patients, including those diagnosed through oncology, acute upper gastrointestinal bleeding, cardiovascular disease, and had hip surgery with risk of cardiovascular disease [13-18].

Anemia is prevalent in critically ill patients, and the hemoglobin concentration is a very important reference standard for red-cell transfusion [19]. The insufficiency of reliable clinical and laboratory evidence on red-cell transfusion may lead to the hemoglobin concentration becoming the main trigger for red-cell transfusion for intensivists [20]. Actually, for those critically ill patients with non-bleeding diseases, the hemoglobin threshold of $70 \mathrm{~g} / \mathrm{L}$ or lower concentration could be well tolerated without the trend of worse survival [21-23]. Clinical guidelines from the American Association of Blood Banks (AABB) also recommended the criteria of red-cell transfusion with hemoglobin concentrations of $70 \mathrm{~g} / \mathrm{L}$ or less in critically ill adults [24]. After the TRICC trials, Holst et al. [25] indicated that 90-day mortality and rates of ischemic events were similar between restrictive and liberal transfusion pilots among intensive care unit (ICU) patients with septic shock. The results of both randomized controlled trials (RCTs) also showed that similar mortality occurred in transfusion and restrictive transfusion groups and the restrictive transfusion strategy was safe compared with liberal transfusion in stable pediatric ICU patients $[26,27]$. It seemed that the hemoglobin concentration trigger of $70 \mathrm{~g} / \mathrm{L}$ had become an accepted transfusion practice in patients with stable hemodynamics and the absence of active bleeding and unstable angina.

However, in an RCT on patients admitted to the ICU after major surgery for abdominal cancer, researchers found that liberal transfusion had lower mortality at 30 and 60 days, and a reduced incidence of intraabdominal infection and cardiovascular events compared with restrictive transfusion [28]. Simultaneously, the Transfusion Requirements in Critically Ill Oncologic Patients Randomized Controlled Trial (TRICOP) also indicated that liberal transfusion had a trend toward a survival benefit in critically ill patients compared with the restrictive transfusion strategy [29]. Furthermore, RCTs using transfusion triggers are in principle limited by the fact that they do not control for normovolemia while allocating different transfusion strategies on the basis of hemoglobin concentrations. Therefore, these conflicting conclusions had created uncertainty among clinicians regarding transfusion practice. We aimed to examine whether a restrictive transfusion strategy was superior to a liberal transfusion strategy in reducing mortality among ICU patients.

\section{Methods}

The target literature we retrieved included the comparison between a restrictive transfusion strategy and liberal transfusion strategy, with outcomes including mortality.

\section{Search Methods}

Two search routes were adopted to respectively identify correlative studies in the MEDLINE, EMBASE, PubMed, Web of Science, and the Cochrane Library Central Register of Controlled Trials databases from inception to January 12, 2019, with the keywords: "blood," "erythrocyte*," "red cell*," "red blood cell*," "RBC," "whole blood," "erythrocyte transfusion," "transfusion," "restrictive," "restrict*," "conservative," and "liberal." One search route was limited to meta-analyses or systematic reviews, and the other was restricted to published RCTs. Finally, eligible RCTs were selected from these two search routes. We did not cover additional unpublished data or unpublished studies. There were no date restrictions, but language was restricted to English and the population was restricted to critically ill adults.

\section{Selection Criteria}

We enrolled those RCTs involving critically ill adults receiving restrictive red-cell transfusion or liberal red-cell transfusion and reporting mortality. The inclusion criteria were: (1) age of 18 years 


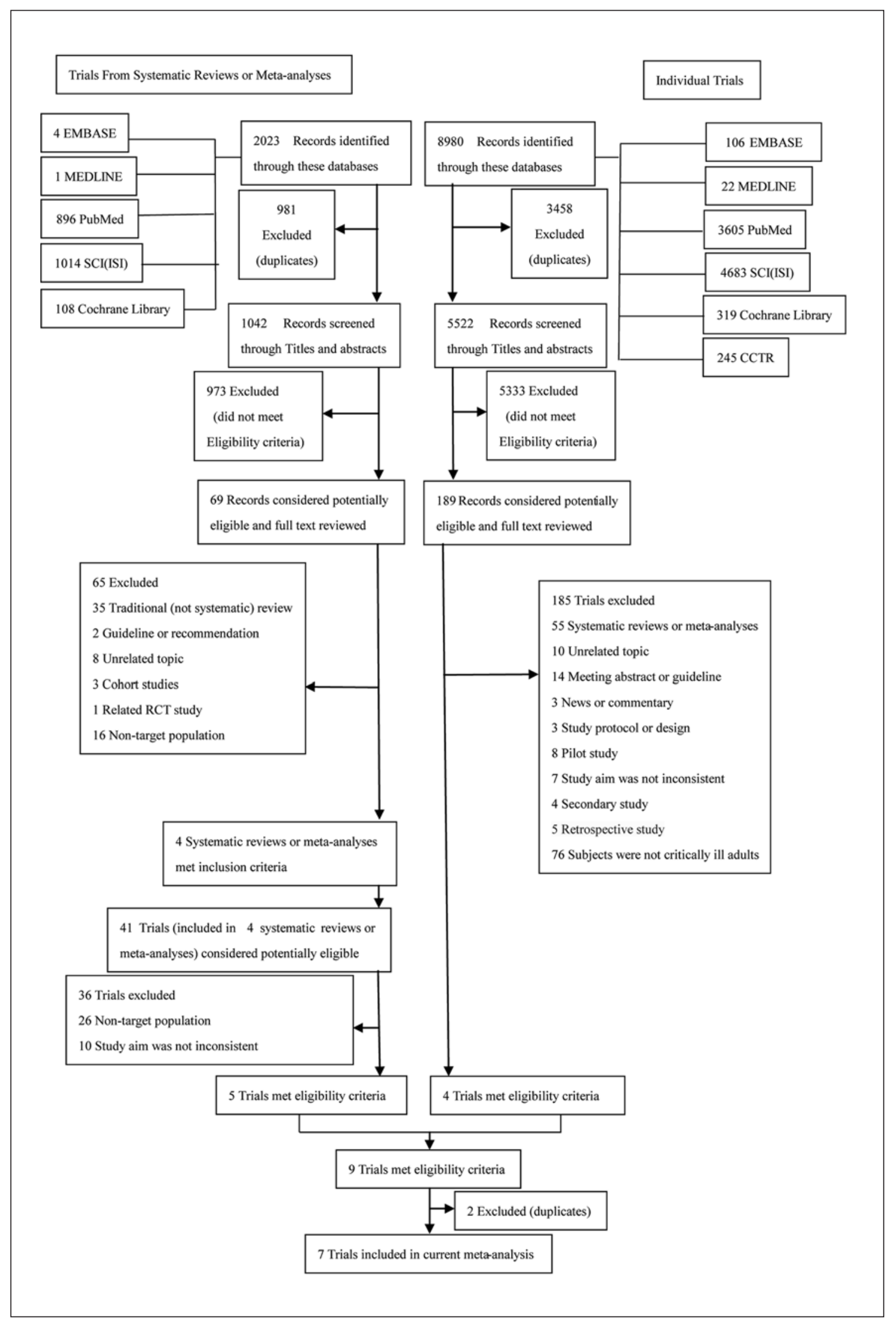

Fig. 1. Study flow chart. 


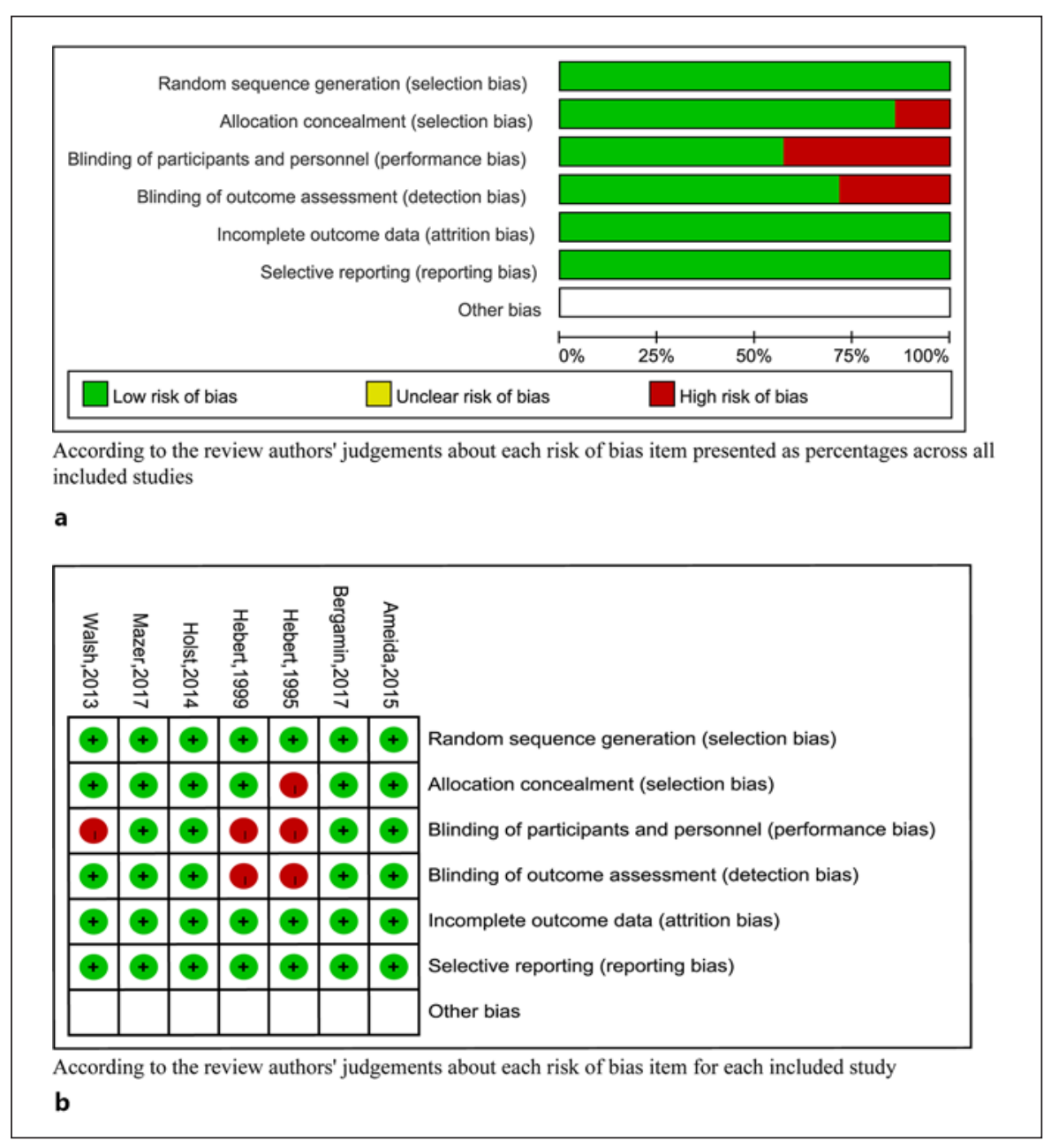

Fig. 2. a Risk of bias graph. b Risk of bias summary. Outcomes of liberal versus restrictive transfusion in critically ill adults.

or more; (2) hemoglobin concentration of $90 \mathrm{~g} / \mathrm{L}$ or less after admission to an ICU; (3) comparison between restrictive and liberal red blood cell transfusion; (4) all-cause mortality was reported as an endpoint. The exclusion criteria were: (1) unable to retrieve the full articles; (2) the study did not meet the inclusion criteria; (3) the trial did not contain adequate data for inclusion; (4) studies of neonates and children in ICUs.

\section{Collection and Extraction of Data}

After duplicate records were removed via mechanical and manual methods, 2 reviewers screened the retrieved results through titles and abstracts. If it was difficult to decide whether the study met the inclusion criteria through the titles and abstracts, it was necessary to gain access to the full text to further evaluate. Data from the trials, including author, country, designs, methods, sample size, participant characteristics, interventions, and mortality, were extracted and analyzed independently by 2 reviewers. The primary outcome was mortality of critically ill adults with anemia in the study, and we had not developed the secondary outcomes. We extracted the data of mortality at 28/30-, 60-, 90-, 120-, and 180-day follow-up endpoints.

\section{Risk of Bias Assessment}

We used the Cochrane Risk of Bias Tool to assess each included study, and their methodological design was also assessed with the following specific elements: (1) randomization sequence generation (selection bias); (2) allocation concealment (selection bias); (3) blinding for study personnel and participants (performance bias); (4) blinding of outcome assessors (performance bias); (5) incomplete reporting of data (attrition bias); (6) selective reporting (reporting bias), and (7) other sources of bias. A study was considered at low risk of bias if each risk of bias item was rated as low risk with the exception of blinding, because blinding of hemoglobin threshold-guided transfusion is difficult. Other studies were assessed as unclear or at high risk of bias.

\section{Statistical Analyses}

All statistical analyses were performed using RevMan version 5.3 and the Mantel-Haenszel method and a fixed-effects or a random-effects model. We calculated risk ratios (RRs) for dichotomous variables, with $95 \%$ confidence intervals (CI). A $p$ value $<0.05$ was considered statistically significant and all statistical tests were two-sided. Heterogeneity among studies was examined using $\chi^{2}$ and $I^{2}$ tests, and heterogeneity existed with $p \leq 0.1$.

\section{Results}

Figure 1 shows the study flow chart and details the explicit searching and screening procedure. Through searching five databases in the meta-analysis route and six databases in the RCT route, there were 2,023 and 8,980 search results obtained, respectively; 1,042 and 5,522 re- 
Fig. 3. Restrictive versus liberal transfusion in critically ill adults for: ICU mortality (a), in-hospital mortality (b), 28/30-day mortality (c), 60-day mortality (d), 90-day mortality (e), 120-day mortality (f), and 180-day mortality $(\mathbf{g})$.

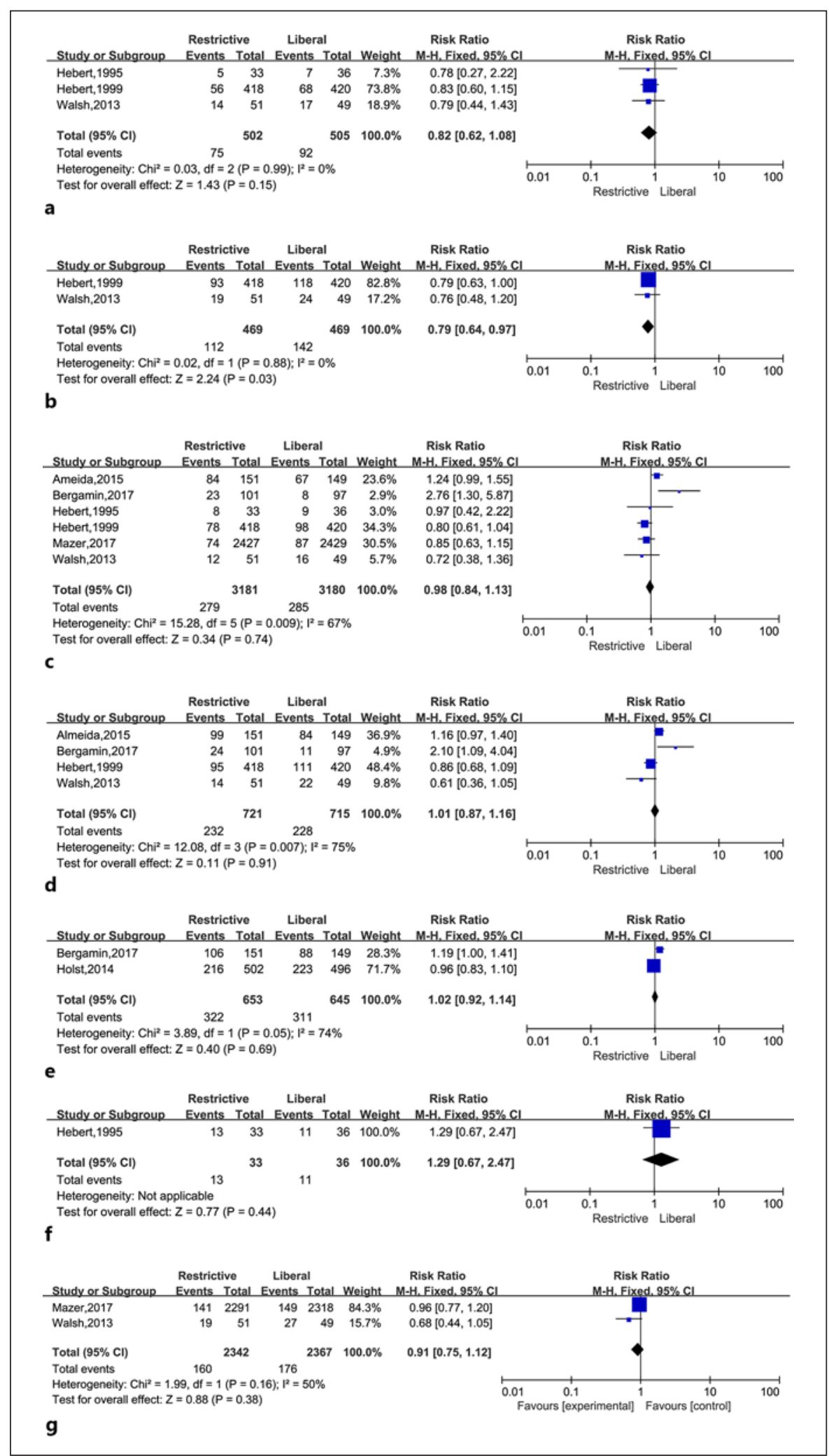

sults remained after omitting duplicate records. In the search records of meta-analyses or systematic reviews, 973 records were removed after checking topics and abstracts and 69 potentially eligible records remained based on the inclusion criteria. Among them, 65 records were excluded because they were a traditional (not systematic) review, guideline or recommendation, unrelated topic, cohort study, RCT, or featured a non-target population; 4 systematic reviews or meta-analyses embracing 41 trials met the inclusion criteria. Finally, 5 of the 41 trials met 
Table 1. Characteristics of the included RCTs

a Study details and APACHE II scores

\begin{tabular}{|c|c|c|c|c|c|c|c|c|c|}
\hline \multirow[t]{2}{*}{ Study } & \multirow[t]{2}{*}{ Country } & \multicolumn{2}{|c|}{ Sample size, $n$} & \multicolumn{2}{|l|}{ Age, years } & \multicolumn{2}{|l|}{ Male, $n(\%)$} & \multicolumn{2}{|c|}{ APACHE II score } \\
\hline & & $\begin{array}{l}\text { restrictive } \\
\text { transfusion }\end{array}$ & $\begin{array}{l}\text { liberal } \\
\text { transfusion }\end{array}$ & $\begin{array}{l}\text { restrictive } \\
\text { transfusion }\end{array}$ & $\begin{array}{l}\text { liberal } \\
\text { transfusion }\end{array}$ & $\begin{array}{l}\text { restrictive } \\
\text { transfusion }\end{array}$ & $\begin{array}{l}\text { liberal } \\
\text { transfusion }\end{array}$ & $\begin{array}{l}\text { restrictive } \\
\text { transfusion }\end{array}$ & $\begin{array}{l}\text { liberal } \\
\text { transfusion }\end{array}$ \\
\hline Mazer [32], 2017 & European & 2,430 & 2,430 & $72 \pm 10$ & $72 \pm 10$ & $1,553(63.9)$ & $1,586(65.3)$ & & \\
\hline Bergamin [29], 2017 & Brazil & 151 & 149 & $61.4 \pm 13.5$ & $61.6 \pm 12.9$ & $84(56.0)$ & $70(47.0)$ & & \\
\hline de Ameida [28], 2015 & Brazil & 101 & 97 & $64 \pm 12$ & $64 \pm 14$ & $55(54.5)$ & $55(56.7)$ & & \\
\hline Hébert [30], 1995 & Canada & 33 & 36 & $58.6 \pm 15$ & $59 \pm 21$ & $14(42.0)$ & $19(53.0)$ & $20 \pm 6.2$ & $21 \pm 7.2$ \\
\hline Hébert [12], 1999 & Canada & 418 & 420 & $57.1 \pm 18.1$ & $58.1 \pm 18.3$ & $269(64.0)$ & $255(61.0)$ & $20.9 \pm 7.3$ & $21.3 \pm 8.1$ \\
\hline Holst [25], 2014 & $\begin{array}{l}\text { Multinational } \\
\text { (Europe) }\end{array}$ & 502 & 496 & $67(57-73)$ & $67(58-75)$ & $272(54.2)$ & $259(52.2)$ & & \\
\hline Walsh [31], 2013 & UK & 51 & 49 & $67 \pm 7$ & $68 \pm 8$ & $36(70.6)$ & $24(49.0)$ & $20.2 \pm 6.6 \dagger$ & $21.5 \pm 6.4$ \\
\hline
\end{tabular}

b SOFA scores, hemoglobin $(\mathrm{Hb})$, methods, and interventions

\begin{tabular}{|c|c|c|c|c|c|c|}
\hline \multirow[t]{2}{*}{ Study } & \multicolumn{2}{|l|}{ SOFA score } & \multicolumn{2}{|c|}{ Baseline $\mathrm{Hb}, \mathrm{g} / \mathrm{dL}$} & \multirow[t]{2}{*}{ Methods and patients } & \multirow{2}{*}{$\begin{array}{l}\text { Interventions (restrictive transfusion vs. } \\
\text { liberal transfusion) }\end{array}$} \\
\hline & $\begin{array}{l}\text { restrictive } \\
\text { transfusion }\end{array}$ & $\begin{array}{l}\text { liberal } \\
\text { transfusion }\end{array}$ & $\begin{array}{l}\text { restrictive } \\
\text { transfusion }\end{array}$ & $\begin{array}{l}\text { liberal } \\
\text { transfusion }\end{array}$ & & \\
\hline Mazer [32], 2017 & - & - & $13.1 \pm 1.8$ & $13.1 \pm 1.7$ & $\begin{array}{l}\text { An international, open-label, non-inferiority } \\
\text { RCT with participants } 18 \text { years of age or } \\
\text { older who were scheduled to undergo } \\
\text { cardiac surgery }\end{array}$ & $\begin{array}{l}\text { Randomized to restrictive } \mathrm{RBC} \text { transfusion } \\
\text { (trigger } \mathrm{Hb} 7.5 \mathrm{~g} / \mathrm{dL} \text { ) versus liberal RBC } \\
\text { transfusion (trigger } \mathrm{Hb} 9.5 \mathrm{~g} / \mathrm{dL} \text { ) }\end{array}$ \\
\hline Bergamin [29], 2017 & $7(5-9)$ & $6(5-9)$ & 9.6 & 9.7 & $\begin{array}{l}\text { Single center, patients }>18 \text { years old with a } \\
\text { diagnosis of solid cancer and fulfilling the } \\
\text { criteria for septic shock in the first } 6 \mathrm{~h} \text { after } \\
\text { ICU admission }\end{array}$ & $\begin{array}{l}\text { Randomized to restrictive } \mathrm{RBC} \text { transfusion } \\
\text { (trigger } \mathrm{Hb} 7 \mathrm{~g} / \mathrm{dL} \text { ) versus liberal RBC } \\
\text { transfusion (trigger } \mathrm{Hb} 9 \mathrm{~g} / \mathrm{dL} \text { ) }\end{array}$ \\
\hline de Almeida [28], 2015 & - & - & 11.2 & 11.0 & $\begin{array}{l}\text { Randomized, patients }>18 \text { years old who had } \\
\text { a major surgical procedure for abdominal } \\
\text { cancer and required postoperative care in } \\
\text { the ICU }\end{array}$ & $\begin{array}{l}\text { Randomized to restrictive RBC transfusion } \\
\text { (trigger } \mathrm{Hb} 7 \mathrm{~g} / \mathrm{dL} \text { ) or liberal RBC transfusion } \\
\text { (trigger } \mathrm{Hb} 9 \mathrm{~g} / \mathrm{dL} \text { ) }\end{array}$ \\
\hline Hébert [30], 1995 & - & - & - & - & $\begin{array}{l}\text { Multicenter, pilot trial, patients }>18 \text { years } \\
\text { old who were admitted to ICU, were } \\
\text { expected to stay more than } 24 \mathrm{~h} \text {, and had an } \\
\mathrm{Hb} \leq 9 \mathrm{~g} / \mathrm{dL} \text { within } 72 \mathrm{~h} \text { after admission }\end{array}$ & $\begin{array}{l}\text { Randomized to restrictive } \mathrm{RBC} \text { transfusion } \\
\text { (trigger } \mathrm{Hb} 7 \mathrm{~g} / \mathrm{dL} \text {; target } 7-10 \mathrm{~g} / \mathrm{dL} \text { ) or liberal } \\
\text { RBC transfusion (trigger } \mathrm{Hb} 10 \mathrm{~g} / \mathrm{dL} \text {; target } \\
10-12 \mathrm{~g} / \mathrm{dL} \text { ) }\end{array}$ \\
\hline Holst [25], 2014 & $10(8-12)$ & $10(8-13)$ & 8.4 & 8.4 & $\begin{array}{l}\text { Multicenter, patients }>18 \text { years old who were } \\
\text { in the ICU, fulfilled the criteria for septic } \\
\text { shock, and had an } \mathrm{Hb} \leq 9 \mathrm{~g} / \mathrm{dL}\end{array}$ & $\begin{array}{l}\text { Randomized to restrictive } \mathrm{RBC} \text { transfusion } \\
\text { (trigger } \mathrm{Hb} 7 \mathrm{~g} / \mathrm{dL} \text { ) or liberal RBC transfusion } \\
\text { (trigger } \mathrm{Hb} 9 \mathrm{~g} / \mathrm{dL} \text { ) }\end{array}$ \\
\hline Walsh [31], 2013 & $7(2-17)$ & $5(2-14)$ & 8.2 & 8.3 & $\begin{array}{l}\text { Multicenter, pilot trial, patients }>55 \text { years } \\
\text { old who were admitted to ICU requiring at } \\
\text { least } 4 \text { days of mechanical ventilation and } \\
\text { had an } \mathrm{Hb} \leq 9 \mathrm{~g} / \mathrm{dL}\end{array}$ & $\begin{array}{l}\text { Randomized to restrictive } \mathrm{RBC} \text { transfusion } \\
\text { (trigger } \mathrm{Hb} 7 \mathrm{~g} / \mathrm{dL} \text {; target } 7-9 \mathrm{~g} / \mathrm{dL} \text { ) or liberal } \\
\mathrm{RBC} \text { transfusion (trigger } \mathrm{Hb} 9 \mathrm{~g} / \mathrm{dL} \text {; target } \\
9-11 \mathrm{~g} / \mathrm{dL} \text { ) }\end{array}$ \\
\hline
\end{tabular}

Data are presented as the mean \pm SD or $n$ (\%). Scores on the Acute Physiology and Chronic Health Evaluation II (APACHE II) range from 0 to 71 , with higher scores indicating a higher risk of death. The Sequential Organ Failure Assessment (SOFA) has subscores ranging from 0 to 4 for each of six organ systems (cerebral, circulation, pulmonary, hepatic, renal, and coagulation); the aggregated score ranges from 0 to 24 , with higher scores indicating more severe organ failure.

the eligibility criteria. In the published RCT route, 189 out of 5,522 search results were potentially eligible. After deleting irrelevant records of systematic reviews or metaanalyses, unrelated topics, meeting abstracts or guidelines, news or commentaries, study protocols, pilot studies, secondary studies, retrospective studies, and non-target population, 4 trials met the inclusion criteria. Eventually, 7 RCTs which included restrictive blood transfusion versus liberal blood transfusion and mortality among critically ill adults were enrolled in this metaanalysis and 2 were removed because of duplication [12, $25,28-32]$. A study which completely satisfied the inclusion criteria was ruled out because only the abstract was available. Another study that was a secondary analysis of the TRICC trial was also discarded [33].
Table 1 lists the baseline characteristics of the 7 included RCTs. These involved 7,363 critically ill patients, of which 3,686 were randomly assigned to a restrictive transfusion group and 3,677 represented a liberal transfusion group. Three of the 7 trials had APACHE II score data showing less severe illness. The number of deaths in the transfusion groups was extracted from the analysis, and is not included in the table. There were 2 pilot studies in the enrolled studies that reported the rate of death followed up on the 120th and 180th days.

The risk of bias assessment is shown in Figure 3. Four studies were assessed at low risk of bias $[25,28,29,32]$ and 3 at high risk of bias $[12,31,30]$. It was next to impossible to implement blinding for participants and personnel. There was significant inter-study heterogeneity in the 
results of 28/30-day mortality ( $p=0.008, I^{2}=71 \%$ ), 60 day mortality $\left(p=0.007, I^{2}=75 \%\right)$, and 90 -day mortality $\left(p=0.05, I^{2}=74 \%\right)$. Publication bias was not considered because the number of eligible studies was less than ten.

Mortality was the only variable in the meta-analysis. We obtained and analyzed mortality during ICU and hospital stays, covering 28/30-, 60-, 90-, 120-, and 180day mortality of the 7 enrolled trials (Fig. 2).

\section{ICU Mortality}

Three trials analyzed mortality during the ICU stay, including 1,007 critically ill patients $[12,30,31]$. There were 75 out of 502 patients who received restrictive transfusions, and 92 out of 505 who received liberal transfusions died (RR 0.82, 95\% CI 0.62, 1.08, $p=0.15$ ).

\section{In-Hospital Mortality}

Mortality during hospitalization was reported in 2 studies with a total of 938 patients $[12,31]$. The rate of death was $24 \%$ (112 out of 469 patients) in the restrictive transfusion group, and $30.3 \%$ (142 out of 469 patients) in the liberal transfusion group. The RR for the relationship between transfusion strategies and mortality was 0.79 (95\% CI $0.64,0.97, p=0.03$ ) with little heterogeneity $\left(I^{2}=0 \%, p=0.88\right)$.

\section{8/30-Day Mortality}

Six eligible studies with 6,361 patients reported 28/30day mortality. Among them, 2 studies showed 28-day mortality $[29,32]$ and the other four reported 30-day mortality [12, 28, 30, 31]. After the 28/30-day follow-up, 279 out of 3,181 patients in the restrictive transfusion group and 285 out of 3,180 patients in the liberal transfusion group had died (RR $0.98,95 \%$ CI $0.84,1.13, p=0.74$ ).

\section{0-Day Mortality}

The 60-day mortality was reported in four trials, involving 1,436 patients $[12,28,29,31]$. On day 60 , death had occurred in 232 out of 721 patients in the restrictive transfusion arm and in 228 out of 715 patients in the liberal transfusion arm (RR 1.01, 95\% CI 0.87, 1.16, $p=$ $0.91)$.

\section{0-Day Mortality}

Bergamin et al. [29] and Holst et al. [25] reported mortality rates on the 90th day of follow-up. The number of deaths was 322 out of 653 patients in the restrictive strategy and 311 out of 645 patients in the liberal strategy (RR $1.02,95 \%$ CI $0.92,1.14, p=0.69$ ).

\section{0- and 180-Day Mortality}

One study conducted follow-up until the 120th day, and 2 studies continued until the 180th day after transfusion and presented mortality data $[30,31,34]$. The 120 - day (RR 1.29, 95\% CI $0.67,2.47, p=0.44$ ) and 180-day mortality rates (RR $0.91,95 \%$ CI $0.75,1.12, p=0.38$ ) were similar between the restrictive and liberal transfusion groups.

There was no statistically significant difference in ICU mortality at $28 / 30,60,90,120$, and 180 days when the restrictive red-cell transfusion strategy was compared with the liberal strategy among critically ill adults with anemia. However, in-hospital mortality for the red-cell transfusion strategy was statistically significantly different compared with the liberal strategy in the study.

\section{Discussion}

In this meta-analysis, we determined that the restrictive red-cell transfusion strategy was potentially superior to the liberal one, showing that it will be an option in future clinical practice. However, RCTs using transfusion triggers are in principle limited by the fact that they do not control for normovolemia while allocating different transfusion strategies on the basis of hemoglobin concentrations.

Theoretically, critically ill adults represent a special type of patient suffering from an unstable hemodynamic state, multiple organ dysfunction syndrome, or comorbidities due to their fragile organ compensatory function, which cause most clinicians to hold the view that a greater hemoglobin level could facilitate oxygen transport in them. This is the essential reason why a great number of physicians have devoted themselves to relevant research in this area for many years. A lower hemoglobin level may mean a poor prognosis in critically ill patients. A recent meta-analysis with 27 RCTs including surgical and critically ill patients suggested that a restrictive transfusion strategy was associated with a significantly reduced 30 day mortality in critically ill patients (OR $0.82,95 \%$ CI $0.70,0.97, p=0.019$ ), but this mortality was increased in surgical patients compared with a liberal transfusion strategy (OR 1.31, 95\% CI 0.94, 1.82, $p=0.12$ ) [35]. Many studies suggested that a restrictive transfusion strategy was as safe as a liberal transfusion strategy and did not show a trend of lower mortality [36-38]. In the TRICC study, the results showed that a restrictive red-cell transfusion strategy had a trend of lower in-hospital mortality in critically ill adults compared with a liberal strategy, but the 30 - and 60 -day mortality rates were negative outcomes, which is consistent with our findings [39]. In another meta-analysis that enrolled perioperative and critically ill patients, the results showed that there was no difference in all-cause mortality among those who received the restrictive redcell transfusion strategy versus the liberal one (OR 1.10, $95 \%$ CI 0.99, 1.23; $p=0.07$ ) [40]. In our meta-analysis, allcause mortality during an ICU stay and follow-up after 
$28 / 30,60,90,120$, and 180 days were similar between the restrictive versus liberal red-cell transfusion strategies. In the analysis on 180-day mortality, we added the new follow-up outcomes from the study by Mazer et al. [34] and still obtained negative outcomes. In this study, in order to avoid selective bias, we also included the RCTs related to critically ill patients with cardiovascular diseases or cardiac surgery since these were prominent patients, despite no difference in outcome for this subgroup.

\section{Strengths of Our Meta-Analysis}

In this meta-analysis, there were three main priorities compared with other studies. Firstly, we performed the first meta-analysis in critically ill adults using all-cause mortality as the outcome and making a comparison between the restrictive red-cell transfusion strategy and the liberal strategy in order to draw conclusions and settle disputes. Secondly, the completeness of data extraction strengthened the reliability of our analysis. Finally, the diversity of the spectrum of included diseases indicated that the results of our study are universally applicable in critically ill adults with anemia.

\section{Weaknesses of our Meta-Analysis}

Despite the several strengths mentioned above, some limitations should not be ignored in this meta-analysis. First of all, despite our target population being restricted to critically ill adults, the various categories of disease may give rise to potential heterogeneity. Additionally, due to the particularity of red-cell transfusion administration, it was difficult to implement the blinding method in this study. Furthermore, we only selected all-cause mortality as the primary outcome without analyzing other secondary outcomes, which may be insufficient. Finally, although the sample size in the study reached 7,363 , it was still insufficient compared with other studies. Consequently, it will be pertinent to design a multicenter, largesample, clinical controlled trial to overcome these limitations in the future.

\section{Conclusions}

In the study, we found that the restrictive red-cell transfusion strategy potentially reduced in-hospital mortality in critically ill adults with anemia compared with the liberal strategy.

\section{Acknowledgments}

We thank the investigators and patients of all the RCTs contained in this meta-analysis for providing the data, and Li Ling (assistant researcher at the Chinese Cochrane Centre, Chengdu, China) for her help with the search strategy, literature search, and methodological guidance for the data analyses. Finally, we thank Ellen Knapp, PhD, from Liwen Bianji, Edanz Group China (www. liwenbianji.cn/ac) for editing the English text of a draft of this manuscript.

\section{Statement of Ethics}

The review and consent of the ethics committee was not required for this research owing to the participants coming from published studies. Informed consent of included patients was not required for publication due to the research being a meta-analysis of randomized controlled trials.

\section{Disclosure Statement}

The authors declare that they have no competing interests.

\section{Funding Sources}

This study was supported by the Zunyi Medical College 2017 Academic New Seedling Cultivation and Innovative Exploration Fund (Qian Ke He Talents Platform [2017] 5733-019) and Science and Technology Support Plan of Guizhou Province in 2019 (Qian Ke He Support [2019] 2834).

\section{Author Contributions}

W.Z. had full access to all of the data in the present study and accepts responsibility for data management and the accuracy of data analyses. Study concept and design: W.Z., K.Y., and Y.Z. Acquisition, analyses, and interpretation of data: W.Z., K.Y., and J.G. Drafting of the manuscript: W.Z. and K.Y. Critical revision of the manuscript for important intellectual content: W.Z. and J.G. Administrative, technical, or material support: W.Z. and Y.Z. Study supervision: W.Z. and J.G. All authors agreed to the submission of the final version of this manuscript. W.Z. is the study guarantor.

\section{References}

1 Corwin HL. Anemia and blood transfusion in the critically ill patient: role of erythropoietin. Crit Care. 2004;8 Suppl 2:S42-4.

2 Corwin HL. Anemia and red blood cell transfusion in the critically ill. Semin Dial. 2006 Nov-Dec;19(6):513-6.

3 Corwin HL, Gettinger A, Pearl RG, Fink MP, Levy MM, Abraham E, et al. The CRIT Study: anemia and blood transfusion in the critically ill-current clinical practice in the United States. Crit Care Med. 2004 Jan; 32(1):39-52.

4 Raghavan M, Marik PE. Anemia, allogenic blood transfusion, and immunomodulation in the critically ill. Chest. 2005 Jan;127(1): 295-307.

5 Toy P, Popovsky MA, Abraham E, Ambruso DR, Holness LG, Kopko PM, et al.; National Heart, Lung and Blood Institute Working Group on TRALI. Transfusion-related acute lung injury: definition and review. Crit Care Med. 2005 Apr;33(4):721-6. 
6 Zallen G, Offner PJ, Moore EE, Blackwell J, Ciesla DJ, Gabriel J, et al. Age of transfused blood is an independent risk factor for postinjury multiple organ failure. Am J Surg. 1999 Dec;178(6):570-2.

7 Vincent JL, Baron JF, Reinhart K, Gattinoni L, Thijs L, Webb A, et al.; ABC (Anemia and Blood Transfusion in Critical Care) Investigators. Anemia and blood transfusion in critically ill patients. JAMA. 2002 Sep;288(12): 1499-507.

8 Forbes JM, Anderson MD, Anderson GF, Bleecker GC, Rossi EC, Moss GS. Blood transfusion costs: a multicenter study. Transfusion. 1991 May;31(4):318-23.

9 Odutayo A, Desborough MJ, Trivella M, Stanley AJ, Dorée C, Collins GS, et al. Restrictive versus liberal blood transfusion for gastrointestinal bleeding: a systematic review and meta-analysis of randomised controlled trials. Lancet Gastroenterol Hepatol. 2017 May;2(5):354-60.

10 Hébert PC; Transfusion Requirements in Critical Care Investigators and the Canadian Critical Care Trials Group. Red cell transfusion strategies in the ICU. Vox Sang. 2000;78 Suppl 2:167-77.

11 Zilberberg MD, Shorr AF. Effect of a restrictive transfusion strategy on transfusion-attributable severe acute complications and costs in the US ICUs: a model simulation. BMC Health Serv Res. 2007 Aug;7(1):138.

12 Hébert PC, Wells G, Blajchman MA, Marshall J, Martin C, Pagliarello G, et al. A multicenter, randomized, controlled clinical trial of transfusion requirements in critical care. Transfusion Requirements in Critical Care Investigators, Canadian Critical Care Trials Group. N Engl J Med. 1999 Feb;340(6):409-17.

13 Prescott LS, Taylor JS, Lopez-Olivo MA, Munsell MF, VonVille HM, Lairson DR, et al. How low should we go: a systematic review and meta-analysis of the impact of restrictive red blood cell transfusion strategies in oncology. Cancer Treat Rev. 2016 May;46:1-8.

14 Villanueva C, Colomo A, Bosch A, Concepción M, Hernandez-Gea V, Aracil C, et al. Transfusion strategies for acute upper gastrointestinal bleeding. N Engl J Med. 2013 Jan; 368(1):11-21

15 Docherty AB, O’Donnell R, Brunskill S, Trivella $\mathrm{M}$, Doree $\mathrm{C}$, Holst $\mathrm{L}$, et al. Effect of restrictive versus liberal transfusion strategies on outcomes in patients with cardiovascular disease in a non-cardiac surgery setting: systematic review and meta-analysis. BMJ. 2016 Mar;352:i1351.

16 Carson JL, Terrin ML, Noveck H, Sanders DW, Chaitman BR, Rhoads GG, et al.; FOCUS Investigators. Liberal or restrictive transfusion in high-risk patients after hip surgery. N Engl J Med. 2011 Dec;365(26):245362.

17 Carson JL, Brooks MM, Abbott JD, Chaitman B, Kelsey SF, Triulzi DJ, et al. Liberal versus restrictive transfusion thresholds for patients with symptomatic coronary artery disease. Am Heart J. 2013 Jun;165(6):964-971.e1.
18 Wang Y, Shi X, Wen M, Chen Y, Zhang Q Restrictive versus liberal blood transfusion in patients with coronary artery disease: a metaanalysis. Curr Med Res Opin. 2017 Apr;33(4): 761-8.

19 Lobo SM, Vieira SR, Knibel MF, Grion CM, Friedman G, Valiatti JL, et al. [Transfusion practices in brazilian Intensive Care Units (pelo FUNDO-AMIB)]. Rev Bras Ter Intensiva. 2006 Sep;18(3):234-41.

20 Walsh TS, Wyncoll DL, Stanworth SJ. Managing anaemia in critically ill adults. BMJ. 2010 Sep;341:c4408.

21 Al-Faris L, Al-Fares AR, Abdul Malek K, Om$\operatorname{ran} \mathrm{A}, \mathrm{Al}-\mathrm{Humood} \mathrm{S}$. Blood transfusion practice in critically ill patients: a single institutional experience. Med Princ Pract. 2012; 21(6):560-5.

22 Tinmouth AT, McIntyre LA, Fowler RA. Blood conservation strategies to reduce the need for red blood cell transfusion in critically ill patients. CMAJ. 2008 Jan;178(1):49-57.

23 Wahl WL, Hemmila MR, Maggio PM, Arbabi S. Restrictive red blood cell transfusion: not just for the stable intensive care unit patient. Am J Surg. 2008 Jun;195(6):803-6.

24 Carson JL, Grossman BJ, Kleinman S, Tinmouth AT, Marques MB, Fung MK, et al.; Clinical Transfusion Medicine Committee of the AABB. Red blood cell transfusion: a clinical practice guideline from the AABB* Ann Intern Med. 2012 Jul;157(1):49-58.

25 Holst LB, Haase N, Wetterslev J, Wernerman J, Guttormsen AB, Karlsson S, et al.; TRISS Trial Group; Scandinavian Critical Care Trials Group. Lower versus higher hemoglobin threshold for transfusion in septic shock. N Engl J Med. 2014 Oct;371(15):1381-91.

26 Lacroix J, Hébert PC, Hutchison JS, Hume HA, Tucci M, Ducruet T, et al.; TRIPICU Investigators; Canadian Critical Care Trials Group; Pediatric Acute Lung Injury and Sepsis Investigators Network. Transfusion strategies for patients in pediatric intensive care units. N Engl J Med. 2007 Apr;356(16):160919

27 Akyildiz B, Ulgen Tekerek N, Pamukcu O, Dursun A, Karakukcu M, Narin N, et al. Comprehensive analysis of liberal and restrictive transfusion strategies in pediatric intensive care unit. J Trop Pediatr. 2018;64(2):118-25.

28 de Almeida JP, Vincent JL, Galas FR, de Almeida EP, Fukushima JT, Osawa EA, et al. Transfusion requirements in surgical oncology patients: a prospective, randomized controlled trial. Anesthesiology. 2015 Jan;122(1): 29-38.

29 Bergamin FS, Almeida JP, Landoni G, Galas FR, Fukushima JT, Fominskiy E, et al. Liberal Versus Restrictive Transfusion Strategy in Critically Ill Oncologic Patients: The Transfusion Requirements in Critically Ill Oncologic Patients Randomized Controlled Trial. Crit Care Med. 2017 May;45(5):766-73.
30 Hébert PC, Wells G, Marshall J, Martin C, Tweeddale M, Pagliarello G, et al. Transfusion requirements in critical care. A pilot study. Canadian Critical Care Trials Group. JAMA. 1995;273(18):1439-44.

31 Walsh TS, Boyd JA, Watson D, Hope D, Lewis $\mathrm{S}$, Krishan A, et al.; RELIEVE Investigators. Restrictive versus liberal transfusion strategies for older mechanically ventilated critically ill patients: a randomized pilot trial. Crit Care Med. 2013 Oct;41(10):2354-63.

32 Mazer CD, Whitlock RP, Fergusson DA, Hall J, Belley-Cote E, Connolly K, et al.; TRICS Investigators and Perioperative Anesthesia Clinical Trials Group. Restrictive or liberal red-cell transfusion for cardiac surgery. N Engl J Med. 2017 Nov;377(22):2133-44.

33 McIntyre L, Hebert PC, Wells G, Fergusson D, Marshall J, Yetisir E, et al.; Canadian Critical Care Trials Group. Is a restrictive transfusion strategy safe for resuscitated and critically ill trauma patients? J Trauma. 2004 Sep; 57(3):563-8.

34 Mazer CD, Whitlock RP, Fergusson DA, Belley-Cote E, Connolly K, Khanykin B, et al.; TRICS Investigators and Perioperative Anesthesia Clinical Trials Group. Six-month outcomes after restrictive or liberal transfusion for cardiac surgery. N Engl J Med. 2018 Sep; 379(13):1224-33.

35 Chong MA, Krishnan R, Cheng D, Martin J. Should transfusion trigger thresholds differ for critical care versus perioperative patients? A meta-analysis of randomized trials. Crit Care Med. 2018;46(2):252-63.

36 Alkhalid Y, Lagman C, Sheppard JP, Nguyen T, Prashant GN, Ziman AF, et al. Restrictive transfusion threshold is safe in high-risk patients undergoing brain tumor surgery. Clin Neurol Neurosurg. 2017 Dec;163:103-7.

37 Holst LB, Petersen MW, Haase N, Perner A, Wetterslev J. Restrictive versus liberal transfusion strategy for red blood cell transfusion: systematic review of randomised trials with meta-analysis and trial sequential analysis. BMJ. 2015 Mar;350:h1354.

38 Ripollés Melchor J, Casans Francés R, Espinosa Á, Martínez Hurtado E, Navarro Pérez R, Abad Gurumeta A, et al.; EAR Group Anesthesia Evidence Review. Restrictive versus liberal transfusion strategy for red blood cell transfusion in critically ill patients and in patients with acute coronary syndrome: a systematic review, meta-analysis and trial sequential analysis. Minerva Anestesiol. 2016 May;82(5):582-98.

39 Chelluri L. Restrictive and liberal blood transfusion strategies had similar mortality rates in critically ill adults. ACP J Club. 1999;131:9.

40 Fominskiy E, Putzu A, Monaco F, Scandroglio AM, Karaskov A, Galas FR, et al. Liberal transfusion strategy improves survival in perioperative but not in critically ill patients. A meta-analysis of randomised trials. Br J Anaesth. 2015 Oct;115(4):511-9. 